\title{
UPAYA PEMERINTAH KABUPATEN KULON PROGO DALAM PENGENDALIAN TEMBAKAU
}

\author{
Mike Dewanti \\ Mahasiswa IImu Pemerintahan, Fakultas IImu Sosial dan Ilmu Politik \\ Universitas Muhammadiyah Yogyakarta \\ mikedewanti14@gmail.com \\ Eko Priyo Purnomo \\ Dosen Ekologi Pemerintahan, Fakultas Ilmu Sosial dan Ilmu Politik \\ Universitas Muhammadiyah Yogyakarta \\ eko.umy@ac.id
}

\author{
Aulia Nur Kasiwi \\ Researcher of Jusuf Kalla School of Government \\ Universitas Muhammadiyah Yogyakarta \\ aluianurkasiwi@gmail.com
}

\begin{abstract}
ABSTRAK
Industri tembakau memang mampu memberikan dampak ekonomi yang baik berupa pendapatan negara dari cukai yang tinggi. Namun, disisi lain industry tembakau yang terus melesat mampu mempengaruhi meningkatnya konsumsi masyarakat terhadap tembakau maupun produk turunannya seperti rokok. Hal tersebut tentunya akan memberikan dampak yang buruk bagi kesehatan. Maka dari itu, pemerintah perlu melakukan berbagai upaya guna mengendalikan konsumsi tembakau. Penelitian ini akan berfokus pada bagaimana upaya yang dilakukan pemrintah Kabupaten Kulon Progo dalam pengendalian tembakau. Penelitian ini menggunakan metode kualitatif dengan pendekatan analisa deskriptif. Peneliti menggunakan metode analisa deskriptif, yaitu suatu analisa yang dimaksudkan untuk menjelaskan data dari satu variabel yang diteliti. Dari hasil penelitian diperoleh informasi bahwa upaya yang telah dilakukan Pemerintah Kabupaten Kulon Progo dalam pengendalian tembakau meliputi penerapan kawasan tanpa rokok, penyediaan tempat khusus merokok, pengendalian iklam, promosi dan sponsor dari produk tembakau, dan mengajak masyarakat untuk berperan serta dalam pengendalian tembakau.
\end{abstract}

\section{Kata Kunci : Tembakau, Pengendalian Tembakau}

\section{Pendahuluan}

Indusrti tembakau dunia sedang dihadapkan pada adanya kontroversi. Disatu sisi, industri tembakau merupakan komoditas penting dalam perdangangan dunia termasuk Indonesia yang mana tembakau memberikan peran bagi ekonomi negara dan dunia. Disisi lain, peningkatan konsumsi tembakau oleh masyarakat menimbulkan dampak yang buruk bari tubuh dan lingkungan (Rachmat \& Aldillah, 2016). Komoditas tembakau dan produk turunan dari tembakau seperti rokok dan produk produk lainnya mempunyai 
nilai ekonomi tinggi serta merupakan sumber pendapatan petani, penerimaan pemerintah dari dalam negeri dan kesempatan kerja (Hadi \& Friyatno, 2008).

Berdasarkan data dari Direktorat Jenderal Perbendaharaan Negara bahwa penerimaan negara dari cukai tembakau selama lima tahun sejak 2010 hingga 2014 selalu mengalami trend kenaikan yang signifikan. Menurut data Direktorat Jenderal Bea dan Cukai, Kemenkeu RI jumlah realisasi penerimaan negara dari cukai tembakau cenderung selalu diatas target $100 \%$ (Santoso, 2017). Aliansi Masyarakat Tembakau Indonesia (AMTI) mengemukakan bahwa industri rokok merupakan salah satu industri yang menciptakan banyak lapangan pekerjaan. Sekitar 6,1 juta lapangan pekerjaan diciptakan dari total 995 produsen produk tembakau yang terdaftar di Indonesia (Fajriah, 2017). Namun, disamping penerimaan negara dan kesempatan kerja, tembakau dengan rokoknya telah dinilai membawa dampak bagi kesehatan (Santoso, 2017).

Dari produksi tembakau yang menghasilkan rokok, dalam setiap kepulan asap rokok terdapat \pm 4000 racun kimia yang berbahaya dan 43 diantaranya mempengaruhi pertumbuhan sel kanker (Abadi, 2005; Sinaga, 2016). Sekitar $80 \%$ perokok di Indonesia memulai kebiasaannya tersebut sebelum berumur 19 tahun. Itu menunjukkan bahwa Indonesia merupakan negara yang memiliki jumlah perokok remaja terbanyak di dunia. (Setyoadi, 2013; Chotidjah, 2013). Dari 1,3 miliar perokok dunia, sebanyak 4,8\% ada di Indonesia sehingga. Maka dari itu tidak heran jika Indonesia menduduki urutan ke-3 jumlah perokok terbesar dunia setelah India dan Cina (Widati, 2013). Akibat dari konsumsi tembakau, terjadi kenaikan penderita penyakit akibat konsumsi tembakau dari 384.058 orang pada tahun 2010 menjadi 962.403 orang pada tahun 2013 (Santoso, 2017). Penyebab utama terbesar kematian yang sulit dicegah dalam masyarakat adalah diakibatkan oleh efek dari merokok. Pada tahun 1950, setiap tahun hanya ada sekitar kurang lebih 300.000 kematian akibat kebiasaan merokok. Angka ini mengalami lonjakan yang tinggi menjadi 1 juta kematian pada tahun 1965; 1,5 juta di tahun 1975, dan menjadi 3 juta kematian pada tahun 1990-an (Rahmah, 2015). Di tahun 2030 diperkirakan angka kematian akibat rokok sebesar 10 juta jiwa, dan sebagian besar dari Negara berkembang (70\%) (Kemenkes RI, 2016).

Dari laporan kesehatan Dinas Kesehatan Provinsi Daerah Istimewa Yogyakarta tahun 2017 , Prosentase kebiasaan merokok penduduk usia 5 tahun 
ke atas di Kabupaten Kulon Progo pada tahun 2017 menunjukkan angka $17,78 \%$. Angkat tersebut menunjukka peringkat ke 2 setelah Kabupaten Gunung Kidul sebesar 19,21 \% (Susenas, 2017; Dinas Kesehatan Prov. DIY, 2017). Di Kabupaten Kulon Progo tahun 2016, dari 20 besar penyakit penyebab kematian, penyakit jantung menempati urutan ke 5 dan hipertensi urutan ke 6 (Dinkes Kulon Progo, 2016; Setyaningrum et al., 2019). Salah satu penyebab penyakit jantung coroner adalah merokok. Semakin banyak jumlah rokok maupun asap rokok yang dihisap per harinya, maka total kolesterol juga akan meningkat (Dinkes Kulon Progo, 2017; (Setyaningrum et al., 2019).

Namun, sebagai Kabupaten dengan prosentase perokok tertinggi ke 2 se Provinsi DIY, dari ke 5 kabupaten di Daerah Istimewa Yogyakarta, Kabupaten Kulon Progo merupakan satu satunya kabupaten yang mendapat penghargaan Pastika Parama terkait penetapan dan pengimplementasian Perda KTR serta kebijakan lain yang terkait denga pengendalian konsumsi hasil tembakau untuk Kabupaten Kulonprogo pada tahun 2017 dan Pastika Awya Pariwara dari Kementerian Kesehatan RI tahun 2018 (Kemenkes.go.id, 2018). Untuk mampu meraih penghargaan tersebut, tentunya diperlukan kontribusi yang baik antar semua pihak. Maka dari itu, yang menarik dijadikan penelitian adalah bagaimana Kabupaten Kulon Progo mengendalikan tembakau serta produk turunannya, sementara kita tau bahwa Kabupaten dengan prosentase perokok tertinggi ke 2 se Provinsi DIY, dari ke 5 provinsi yang berada di Daerah Istimewa Yogyakarta, Kabupaten Kulon Progo adalah satu satunya kabupaten yang mendapat penghargaan Pastika Awya Pariwara dari Kementerian Kesehatan RI tahun 2018 . Maka dari itu penelitian ini mempunyai tujuan untuk mengetahui bagaimana strategi yang dilakukan Pemerintah Kabupaten Kulon Progo untuk menekan konsumsi rokok di Kabupaten Kulon Progo.

\section{Tinjauan Pustaka}

Pengendalian tembakau, penerapan kebijakan harga rokok, pengendalian iklan rokok, kegiatan promosi dan sponsor oleh perusahaan rokok, penetapan pajak atau cukai rokok, serta penetapan daeerah atau kawasan bebas udara dari asap rokok adalah upaya yang dapat dilakukan pemerintah dalam rangka meminimalkan dampak buruk dari bat senyawa berbahaya serta konstaminasi dan polusi udara (Rachmat \& Aldillah, 2016). 
Menurut Mardhiati (2017), Gerakan Pengendalian Tembakau merupakan gerakan yang mutlak dibutuhkan di Indonesia sebagai suatu upaya perlindungan kepada mansyarakat yang tidak merokok dan mengajak masyarakat yang yang merokok untuk dapat berhenti merokok. Dalam pengendalian tembakau, Ahsan (2018) menyebutkan terdapat 5 komponen regulasi. Pertama, melindungi penduduk dari paparan asap atau kawasan tanpa rokok. Kedua, menawarkan program berhenti merokok nasional. Ketiga, penerapan larangan iklam rokok. Keempat, Peringatan bahaya merokok. Kelima, menaikkan cukai rokok dengan indikator presentase cukai terhadap harga rokok.

Salah satu negara yang juga konsisten dalam pengendalian rokok/tembakau adalah Singapura. Strategi yang diimplementasikan Singapura dalam pengendalian rokok/ tembakau adalah regulasi mengenai iklan dan promosi mengenai tembakau, regulasi dalam perpajakan, regulasi dalam kemasan dan pelabelan produk tembakau, regulasi pelarangan konsumsi tembakau di lokasi-lokasi tertentu, edukasi dan pelatihan pada masyarakat mengenai tembakau, regulasi dalam penjualan produk tembakau, upaya dalam penurunan ketergantungan pada tembakau dan berhenti merokok (Nadhilah, 2016).

Menurut Santoso (2017), kebijakan pengendalian tembakau harus mempertimbangkan aspek penerimaan negara, kesehatan masyarakat dan ketenaga kerjaan. Sementara itu terdapat beberapa peneliti yang memberikan gambaran upaya yang dapat dilakukan pemerintah Indonesia dalam pengendalian tembakau. Zonasi pemetaan areal tanaman tembakau, pengembangan tembakau rendah nikotin dan mencari alternative produk turunannya merupakan upaya yang dapat dilakukan dalam pengendalian tembakau di Indonesia (Hasan \& Darwanto, 2016). Tujuan kebijakan harus mampu mengakomodir langkah-lagkah yang diperlukan dalam mengatasi eksternalitas negative akibat merokok, tingkat retribusi harus dirubah dari tingkat kabupaten/kota menjadi tingkat provinsi untuk meningkatkan lingkup kebijakan dan ruang lingkup tindakan, serta dasar alokasi harus didesain ulang karena dasar alokasi saat ini akan mendorong pemerintah daerah untuk meningkatkan produksi rokok daripada mengendalikannya (Mayor \& Sitepu, 2016). 
Nuhung dan Adilah berpendapat sama bahwa pengendalian tembakau tanpa mencari substitusi lain dan tanpa menurunkan tingkat perokok hanya akan mempengaruhi ekonomi Indonesia terutama dalam hal import dan eksport. Maka dari itu, komoditi pengganti sangat diperlukan untuk mendongkrak kestabilan ekonomi Indonesia (Nuhung, 2014; Rachmad 2016). Sejalan dengan Nuhung dan Aldilah, Suprihatin juga berpendapat bahwa pengendalian tembakau dan kampanye bahaya rokok dapat merubah pola konsumsi masyarakat yang beralih ke rokok rendah nikotin, hal tersebut tentunya mempengaruhi kegiatan impor negara. Petani didorong untuk mampu berinisiatif mengusahakan jenis tembakau rendah nikotin (Suprihanti, 2018).

Menurut Khanifa, Pengendalian tembakau dengan meniadakan perspektif lainnya seperti ekonomi, social dan budaya dan hanya focus pada perspektif kesehatan saja tidaklah suatu tindakan yang tepat (Khanifa, 2018). Dalam hal pengendalian rokok atau tembakau, pemberian iklan bahaya konsumsi tembakau berlebih atau merokok yang menakut-nakuti kurang efektif karena tidak merubah pola konsumsi perokok (Andini, 2019). Hadi juga menyatakan dalam jurnalnya bahwa produksi tembakau selama periode 20002006 memang mengalami penurunan, namun disamping itu konsumsi rokok perkapita cenderung naik seiring dengan naiknya pendapatan perkapita (Hadi \& Friyatno, 2008). Maka dari itu, untuk mampu mengendalikan tembakau dengan baik dan mengurangi konsumsi rokok di Indonesia diperlukan kontribusi dari semua pihak baik pemerintah, swasta maupun masyarakat. Pemerintah perlu memberikan pemahaman kepada swasta dan masyarakat terutama petani tembakau mengenai isi, maksud dan tujuan regulasi tentang pengendalian tembakau. Hal ini dimaksudkan agar tidak ada satu elemen pun yang merasa dirugikan dengan adanya regulasi tersebut (Handayani, 2012).

\section{Metode Penelitian}

Jenis penelitian yang digunakan dalam tulisan ini adalah jenis penelitian deskriptif dengan menggunakan pendekatan kualitatif. Pendekatan deskriptif kualitatif adalah pendekatan penelitian dengan cara mengumpulkan data-data yang bersumber dari hasil wawancara, catatan lapangan, video tape, foto, catatan, dokumentasi pribadi, atau memo dan data lainnya. Data yang 
dikumpulkan berupa data kata-kata, gambar-gambar dan bukan angka (Moleong, 2005; Yanuar, 2019) Penelitian yang bersifat deskriptif bertujuan untuk membuat suatu deskripsi, gambaran ataupun lukisan secara sistematis, akurat dan factual mengenai sifat, fakta serta hubungan antara fenomena yang diselidiki (Nazir, 2005; Yanuar, 2019). Teknik untuk menganalisis data dalam penelitian ini menggunakan data sekunder dan juga tinjauan pustaka untuk mengetahui upaya yang telah dilakukan pemerintah (Burnham, 2004 ; Kasiwi, 2017). Teknik analisis data menggunakan teknik analisis model interaktif yang dikembangkan Miles dan Hubberman yang meliputi tiga tahap yaitu reduksi data, penyajian data dan kemudian penarikan kesimpulan (Moleong, 2010; Suhendri \& Purnomo, 2017).

\section{Pembahasan}

Menjamin kehidupan yang sehat serta mendorong kesejahteraan untuk semua orang disegala usia adalah salah satu tujuan yang harus dicapai dalam sector kesehatan SDGs. Sustainable Development Goals (SDGs) Merupakan upaya pembangunan berkelanjutan yang menjadi acuan dalam kerangka pembangunan dan perundingan Negara-Negara di dunia.Hal tersebut dapat dilakukan melalui mengurangi secara substansial kematian serta kesakitan akibat senyawa berbahaya serta konstaminasi dan polusi udara, air dan tanah (Ermanela, 2017). Berbagai upaya perlu dilakukan pemerintah, swasta dan masyarakat dalam mewujudkan tujuan SDGs dalam bidang kesehatan tersebut. Seperti halnya Pemerintah Kabupaten Kulon Progo. Dalam upaya menekan jumlah konsumsi tembakau, Pemerintah Kabupaten Kulon Progo menerapkan beberapa strategi seperti penerapan kawasan tanpa rokok, tempat khusus merokok, kebijakan terkait promosi, iklan niaga serta sponsor produk tembakau, serta mengajak masyarakat untuk berperan serta dalam pengendalian tembakau.

\section{Kawasan Tanpa Rokok}

Upaya yang dilakukan Pemerintah Kabupaten Kulon Progo sebagai wujud memerangi dan menekan jumlah konsumsi tembakau maupun produk turunan tembakau adalah dengan cara menerapkan kawasan tanpa rokok. Menurut Peraturan Daerah Kabupaten Kulon Progo Nomor 5 Tahun 2014 
Tentang Kawasan Tanpa Rokok, yang dimaksud dengan kawasan tanpa rokok adalah ruangan ataupun area yang dinyatakan dilarang untuk dilakukan segala kegiatan merokok atau kegiatan lainnya seperti memproduksi, menjual, mengiklankan, maupun mempromosikan produk tembakau.

Pemerintah Daerah Kabupaten Kulon Progo menerapkan kawasan tanpa rokok meliputi tempat kerja, tempat dilaksanakannya proses belajar mengajar dan kawasan belajar mengajar, tempat ibadah, fasilitas pelayanan kesehatan, angkutan umum, tempat bermain anak, tempat umum dan tempat lain yang ditetapkan. Area yang termasuk dalam area atau kawasan tanpa rokok harus dipasangi tanda larangan merokok yang dipasang di pintu masuk serta dipasang ditempat tengan pencahayaan yang baik agar mudah dilihat.

Namun, upaya dalam menerapkan kawasan tanpa rokok ini tidaklah mudah. Berdasarkan data dari Dinas Kesehatan Kabupaten Kulon Progo, 2 tahun setelah penerapan kebijakan atau tepatnya tahun 2017, dari 200 target lokasi kawasan tanpa rokok, baru 80 lokasi yang menerapkan KRT atau kawasan tampa rokok. Itu berarti baru $40 \%$ dari total targetnya. Kemudian Pemda Kulon Progo semekin gencar dalam melaksanakan kebijakan ini. Hingga akhirnya pada tahun 2019, hampir semua kawasan yang masuk kriteria kawasan tanpa rokok telah mampu menerapkan KRT. Dinas Kesehatan menyatakan bahwa masih ada 2 kawasan yang masih susah dalam penerapan KRT. Dua kawasan itu adalah tempat umum dan kendaraan umum. Penerapan KRT di dua lokasi tersebut cukup sulit karena kompleksnya masyarakat di tempat tersebut.

Sebagai upaya untuk menyukseskan KRT, Pemda Kulon Progo juga memperketat dalam pelaksanaanya. Upaya tersebut dilakukan dengan cara memberi sanksi bagi pemimpin atau penanggung jawab tempat atau kawasan yang masuk kategori KRT namun tidak menerapkan KRT. Selain itu, Pemda juga memberi sanksi bagi masyarakat yang masih melanggar pelaksanaan KRT seperti masih merokok di lokasi KRT. Sanksi tersebut berupa denda sebesar 50.000 rupiah atau kurungan selama 7 hari.

Selain itu, pemerintah kabupaten juga mengelurakan program SemarKu atau Sinergi Bersama Mengurangi Asap Rokok di Kulon Progo untuk mendorong penguatan program KTR. Dengan beranggotakan Sembilan orang, tim SemarKu memiliki tujan utama yaitu menyosialisasikan program KTR dan juga mengajak 
masyarakat untuk terlibat dalam menyukseskan kebijakan KTR di Kabupaten Kulon Progo. Selain itu, mereka memiliki tiga tugas utama yang diemban yaitu melaksanakan fungsi kesekretariatan bupati peduli dampak rokok di Indonesia, memfasilitasi pelaksanaan program pengendalian tembakau serta menjadi tim kerja milenial dalam upaya pengendalian tembakau di Indonesia (Pamungkas, 2019).

Dengan adanya penerapan kawasan tanpa rokok, diharapkan akan menekan konsumsi orang dalam merokok ketika berada di suatu tempat terutama tempat yang menerapkan kawasan tanpa rokok. Selain itu, kawasan tanpa rokok ini juga sebagai wujud perlindungan bagi perokok pasif. Yang mana perokok pasif memiliki dampak terjangkit penyakit arteri koroner, kanker paru dan efek reproduktif pada wanita (Prabandari, Nawi, \& Siwi, 2009).

\section{Tempat Khusus Merokok}

Tempat khusus merokok adalah suatu tempat yang digunakan secara khusus oleh orang untuk merokok agar lingkungan sekitarnya tidak tercemar oleh asap rokok (Agil, Effendy, Sarwoko, \& Setiadi, 2015). Tempat khusus merokok ini diberikan sebagai wujud penerapan kawasan tanpa rokok di Kulon Progo. Sehingga kawasan yang termasuk dalam kawasan tanpa rokok wajib menyediakan tempat khusus merokok. Adapun ketentuan mengenai tempat khusus merokok tersebut adalah sebagai berikut :

a. merupakan tempat atau kawasan terbuka yang berhubungan langsung dengan udara luar ruangan

b. tempat yang terpisah secara fisik dan juga terletak di luar bangunan utama

c. tempat khusus merokok berada paling dekat 5 meter dari pintu masuk dan juga pintu keluar

d. tempat khusus merokok berada paling dekat 5 meter dari tempat berlalu lalang orang

Namun cukup disayangkan, walaupun sudah banyak tempat atau kawasan yang menerapkan kawasan tanpa rokok, namun beberapa diantaranya tidak menyediakan kawasan tanpa rokok. Sehingga banyak perokok yang memilih merokok di tempat parker atau wilayah terbuka lainnya. 


\section{Pengendalian Iklan, Promosi dan Sponsor Produk Tembakau}

Peengendaliann iklan, promosi dan sponsor produk tembakau juga menjadi salah satu upaya yang gencar dilakukan Pemda Kulon Progo dalam menekan konsumsi produk tembakau di Kulon Progo. Pengaturan mengenai larangan iklan, promosi dan sponsor produk tembakau ini termuat dalam Peraturan Daerah Kabupaten Kulon Progo Nomor 5 Tahun 2014 Tentang Kawasan Tanpa Rokok. Dalam Perda tersebut, Pengaturan mengenai iklan rokok tertuang dalam bab III pasal 7. Dalam pasal tersebut diatur mengenai pengendalian iklan produk tembakau yang dilakukan di media luar ruangan dengan ketentuan :

1. Mencantumkan peringatan mengenai kesehatan dalam bentuk gambar dan tulisan minimal $10 \%$ dari total durasi iklan dan/atau $15 \%$ dari total luas iklan

2. Mencantumkan tanda maupun tulisan "18+" dalam iklan produk tembakau

3. Tidak menggunakan, memperagakan dan/atau menampilkan wujud atau bentuk rokok atau produk turunan lain dari tembakau

4. Tidak mencantumkan nama produk yang tembakau tersebut merupakan rokok

5. Tidak menggambarkan ataupun menyarankan bahwa merokok memberikan manfaat bagi kesehatan tubuh

6. Iklan tidak boleh menggunakan kata atau kalimat yang dapat menyesatkan

7. Iklan tidak berisi ajakan untuk merokok

8. Dalam iklan tidak menampilkan gambar dan/atau tulisan anak, remaja dan/atau wanita hamil

9. Iklan tidak ditujukan kepada anak, remaja dan/atau wanita hamil

10. Tidak diperbolehkan memakai tokoh kartun sebagai model iklan

11. Iklan tidak bertentangan dengan norma yang berlaku di masyarakat

Dinas Kesehatan Kulon Progo menjelaskan bahwa pemasangan iklan produk tembakau Tidak boleh dipasang di jalan protokol, di jalan desa, tidak boleh memasang iklan rokok melintang jalan, tidak boleh berdekatan dengan tempat pendidikan, tidak boleh berdekatan dengan pusat layanan kesehatan dan tempat tempat lain yang telah diatur dalam Perda KRT. Sementara itu, terkait dengan promosi dan sponsor, Pemda Kulon Progo juga melarang 
pemberian sponsor dari produk tembakau maupun turunannya dengan niatan untuk promosi, degan mencantumkan label merk rokok/tembakau dan melarangnya diliput oleh media. Dengan kata lain, pemberian sponsor boleh dilakukan asalkan tidak mencantumkan atau menyebutkan produk pemberi sponsor (dalam hal ini produk tembakau maupun turunannya seperti rokok dan lain-lain). Satuan Polisi Pamong Praja /Satpol PP dikerahkan dalam upaya penertipan iklan tembakau maupun produk turunannya yang ada di Kulon progo.

\section{Peran Serta Masyarakat}

Dalam menjalankan pemerintahan terutama terkait pelaksanaan kebijakan, peran serta masyarakat sangatlah penting. Selain sebagai tujuan sasaran kebijakan, masyarakat juga diharapkan dapat berkotribusi secara baik dalam proses menyukseskan suatu kebijakan. Peran serta masyarakat ini tentunya juga sebagai upaya dalam menerapkan konsep good governance atau tata kelola pemerintahan yang baik. Dimana dalam pelaksanaan pemerintahan yang baik harus ada interaksi yang solid antara pemerintah, swasta, dan masyarakat (Rasul, 2009).

Pemerintah Daerah Kabupaten Kulon Progo dalam pengimplementasian kebijakan terkait menekan konsumsi tembakau maupun produk turunannya juga mengandeng masyarakat untuk berkontribusi secara langsung. Wujud kontribusi masyarakat dilakukan melalui kelompok, organisasi, lembaga, badan hukum, badan usaha maupun individu/perseorangan. Peran serta masyarakat dalam mensukseskan kebijakan ini dilaksanakan dalam bentuk menerapkan pengaturan kawasan tanpa rokok di lingkungan tempat tinggal masing-masing, penyampaian saran, masukan dan juga pendapat dalam penetapan, pelaksanaan sampai dengan evaluasi kebijakan penyelenggaraan kawasan tanpa rokok , berkontribusi dalam kegiatan penyelenggaraan dan pengendalian penyelenggaraan kawasan tanpa rokok melalui pengawasan social dan berperan aktif untuk tidak merokok di dalam ruang atau rumah.

Hingga tahun 2019, dari 963 dusun yang ada di Kulon Progo, sudah 213 dusun yang menerapakan kebijakan larangan merokok. Data tersebut menunjukkan bahwa sudah sekitar 25\% dusun di Kabupaten Kulon Progo telah sadar mengenai bahaya merokok dan telah ikut berkontribusi dalam 
pengendalian tembakau terutam produk turunannya yaitu rokok (Gabrillin, 2019).

\section{Kesimpulan Dan Saran}

Berdasarkan pembahasan diatas, dapat ditarik kesimpulan bahwa, Pemerintah Kabupaten Kulon Progo telah melakukan berbagai upaya dalam upaya pengendalian tembakau, yaitu sebagai berikut :

1. Kawasan Tanpa Rokok

Dalam penerapan kawasan tanpa rokok telah berjalan cukup baik, karena dari semua target kawasan yang memasuki kriteria kawasan tanpa rokok, hanya 2 yang belum mampu terealisasikan yaitu tempat umum dan kendaraan umum.

2. Tempat Khusus Merokok

Penyediaan tempat khusus merokok masih perlu mendapat perhatian karena beberapa kawasan masih belum menyediakan tempat khusus merokok.

3. Pengendalian iklan, promosi serta sponsor dari produk tembakau serta produk turunannya

Upaya ini telah berjalan dengan baik karena mendapat kontribusi dari berbagai pihak terutama dinas kesehatan, satuan polisi pamong praja, dan juga linmas yang dikerahkan secara aktif untuk mengendalikan iklan, promosi, serta sponsor dari produk tembakau.

4. Peran Serta Masyarakat

Peran serta masyarakat dalam pengendalian tembakau di Kulon Progo cuku baik namun masih perlu peningkatan. Hal tersebut diliat dari $25 \%$ dusun di Kulon Progo sudah menerapkan kebijakan larangan merokok.

\section{Saran}

1. Perlunya mendorong setiap kawasan tanpa rokok untuk menyediakan tempat khusus merokok

2. Perlunya upaya yang tegas dalam pengendalian iklan rokok di warungwarung kelontong, hal ini karena masih banyak warung-warung kelontong yang memasang spanduk atau stiker iklan rokok. 
3. Perlunya mendorong masyarakat untuk lebih peduli terhadap bahaya merokok sehingga akan lebih banyak dusun yang ikut menerapkan larangan merokok.

4. Dinas terkiat harus terus melakuka sosialisasi mengenai kebijakan pengendalian tembakau ini sekaligus dibantu oleh tim Semarku.

\section{DAFTAR PUSTAKA}

\section{Jurnal}

Agil, F., Effendy, D., Sarwoko, I. M., \& Setiadi, B. (2015). Kendali Kecepatan Kipas Pembuangan Pada Ruang Khusus Merokok Sebagai Pembersih Dan Pengatur Sirkulasi Udara Berbasis Mikrokontroller. Eproceedings of Engineering, 2(2).

Ahsan, A., Hadi, N., Dewi, W., \& Lanni, P. (2018). Kondisi Sosial Dan Ekonomi Negara-Negara Peratifikasi Framework Convention On Tobacco Control ( FCTC ): Sebuah Pembelajaran Untuk Indonesia.

Andini, A. F. (2019). Kampanye Pengendalian Tembakau Terhadap Penurunan Minat Merokok.

Chotidjah, S. (2013). Pengetahuan Tentang Rokok,Pusat Kendali Kesehatan Eksternal Dan Perilaku Merokok. Makara Human Behavior Studies In Asia, 16(1), 49. Https://Doi.Org/10.7454/Mssh.V16i1.1493

Dinas Kesehatan Prov. DIY. (2017). Profil Kesehatan Provinsi D.I. Yogyakarta Tahun 2017.

Ermanela. (2017). Indikaror Kesehatan Sdgs Di Indonesia. Acta Mathematica Academiae Scientiarum Hungaricae. Https://Doi.Org/10.1007/BF01886316

Hadi, P. U., \& Friyatno, S. (2008). Peranan Sektor Tembakau Dan Industri Rokok Dalam Perekonomian Indonesia: Analisis Tabel I-O Tahun 2000. Jurnal Agro Ekonomi, 26(1), 90-121. Https://Doi.Org/10.21082/Jae.V26n1.2008.90-121

Handayani, A., Nurdjanah, Kresnowati, L., \& Widowati, E. (2012). Kesiapan Petani Tembakau Menghadapi RUU Pengendalian Dampak Produk Tembakau Terhadap Kesehatan Di Kabupaten Temanggung. Jurnal Litbang Provinsi Jawa Tengah, 10(1), 19-26.

Hasan, F., \& Darwanto, H. (2016). Prospek Dan Tantangan Usahatani Tembakau Madura. Sepa, 10(September 2013), 63-70. 
Kasiwi, A. N. (2017). Volunteers Of Ict To Provide Citizen Participation Into Society In Indonesia. International Journal Of Management, Innovation \& Entrepreneurial Research, 3(2), 92-98. Https://Doi.Org/10.18510/Ijmier.2017.325

Khanifa, N. K. (2018). Resistensi Atas Pengendalian Tembakau. Wahana Akademika, 5(April), 50-67.

Mardhiati, R., Fatimah, N., \& Andayani, N. (2017). Dukungan Perokok Dan Bukan Perokok Terhadap Kebijakan Pengendalian Tembakau Di Kota Denpasar Dan Yogyakarta. ARKESMAS (Arsip Kesehatan Masyarakat), 1(2), 75-82. Retrieved From Https://Journal.Uhamka.Ac.Id/Index.Php/Arkesmas/Article/View/507

Mayor, E., \& Sitepu, P. (2016). Kajian Ekonomi \& Keuangan Penerapan Earmarking Cukai Hasil Tembakau Di Indonesia: Regulasi Dan Konsep Ideal The Implementation Of Tobacco Excise Earmarking In Indonesia: Regulation And Ideal Concept. 20(3).

Nadhilah, E. (2016). Strategi Singapura Dalam Pengendalian Konsumsi Tembakau Pada Framework Convention On Tobacco Control (Fctc) Tahun 2010-2014. Implementation Science, 3 No 2, 1-11. Https://Doi.Org/10.4324/9781315853178

Nuhung, I. A. (2014). Telaahan Konversi Tembakau, Suatu Tinjauan Ekonomi. Agribusiness Journal, 8(2), 125-140. Https://Doi.Org/10.15408/Aj.V8i2.5133

Prabandari, Y. S., Nawi, \& Siwi, P. R. (2009). Kawasan Tanpa Rokok Sebagai Alternatif Pengendalian Tembakau Studi Efektivitas Penerapan Kebijakan Kampus Bebas Rokok Terhadap Perilaku Dan Status Merokok Mahasiswa Di Fakultas Kedokteran Ugm, Yogyakarta. Jurnal Manajemen Pelayanan Kesehatan, 12(04), 218-225.

Rachmat, M., \& Aldillah, R. (2016). Agribisnis Tembakau Di Indonesia: Kontroversi Dan Prospek Tobacco Agribusiness In Indonesia : Controversy And Prospects. Pusat Analisis Sosial Ekonomi Dan Kebijakan Pertanian, 20 No.1, 69-80.

Rahmah, N. (2015). Pengaruh Rokok Terhadap Kesehatan. Pengaruh Rokok Terhadap Kesehatan, 01(2), 78.

Rasul, S. (2009). Penerapan Good Governance Di Indonesia Dalam Upaya Pencegahan Tindak Pidana Korupsi. Mimbar Hukum - Fakultas Hukum 
58 | Dewanti, Purnomo, Kasiwi Upaya Pemerintah Kabupaten...

Universitas Gadjah Mada, 21(3), 538-553.

Https://Doi.Org/10.20303/Jmh.V21i3.318

Kemenkes, RI. (2016). Pedoman Pengembangan Kawasan Tanpa Rokok.

Santoso, R. (2017). Dilema Kebijakan Pengendalian Tembakau Indonesia. Kajian, 21(3), 201-219.

Setyaningrum, R. A., Susanto, N., Yuningrum, H., \& Wati, N. A. P. (2019).

Faktor Yang Berhubungan Dengan Hiperkolesterolemia Di Dusun Kopat

Desa Karangsari Kecamatan Pengasih Kabupaten Kulon Progo, DIY. Pendekatan Multidisiplin IImu Dalam Manajemen Bencana, 1-11.

Sinaga, S. E. N. (2016). Hubungan Antara Pengetahuan Tentang Rokok, Teman

Sebaya, Orang Tua Yang Merokok, Dan Iklan Rokok Terhadap Perilaku

Merokok Pada Mahasiswa Akademi Kesehatan X Di Rangkasbitung.

Community Of Publishing In Nursing (COPING), ISSN: 2303-1298, 4, 1-5.

Suhendri, S., \& Priyo Purnomo, E. (2017). Penguatan Kelembagaan Dalam

Pencegahan Dan Pengendalian Kebakaran Hutan Dan Lahan Di Kabupaten

Muaro Jambi Provinsi Jambi. Journal Of Governance And Public Policy, 4(1),

174-204. Https://Doi.Org/10.18196/Jgpp.4175

Suprihanti, A., Harianto, H., Sinaga, B. M., \& Kustiari, R. (2018). Dinamika

Konsumsi Rokok Dan Impor Tembakau Indonesia. SEPA: Jurnal Sosial

$\begin{array}{lllll}\text { Ekonomi Pertanian Dan Agribisnis, } 14(2), & 183 .\end{array}$

Https://Doi.Org/10.20961/Sepa.V14i2.25016

Widati, S. (2013). Efektivitas Pesan Bahaya Rokok Pada Bungkus Rokok

Terhadap Perilaku Merokok Masyarakat Miskin. Jurnal Promosi Kesehatan Dan Pendidikan Kesehatan, 1(2), 105-110.

Yanuar, R. M. (2019). Inovasi Pelayanan Publik ( Studi Kasus: Public Safety Center ( PSC ) 119 Kabupaten Bantul Sebagai Layanan Kesehatan Dan Kegawatdaruratan ). Jurnal IImu Pemerintahan, 04(1), 1-20.

\section{Internet}

Fajriah, L. R. (2017). Industri Rokok Ciptakan Jutaan Lapangan Kerja di Tanah Air. Jakarta: sindonews.com.

Gabrillin, A. (2019). Masyarakat di 200 Dusun di Kulon Progo Menerapkan Larangan Merokok. Kulon Progo: kompas.com. Dipetik May 4, 2020, dari 
https://www.msn.com/id-id/olahraga/berita/masyarakat-di-200-dusun-dikulon-progo-menerapkan-larangan-merokok/ar-AAFfKbC

Kemenkes.go.id. (2018). Berhasil Larang Iklan Rokok di Wilayahnya, 10 Daerah Dapat Penghargaan Pastika Awya Pariwara. Jakarta: Kemenkes.go.id.

Pamungkas, S. (2019). SemarKu Bumikan Aturan tentang Kawasan Tanpa Rokok. Kulon Progo: Tribunjogja.com. Dipetik May 4, 2020, dari https://jogja.tribunnews.com/2019/07/31/semarku-bumikan-aturantentang-kawasan-tanpa-rokok

\section{Peraturan Perundang-undangan}

Peraturan Daerah Kabupaten Kulon Progo Nomor 5 Tahun 2014 Tentang Kawasan Tanpa Rokok 